\title{
Membrane-Initiated Estradiol Signaling of Epithelial-Mesenchymal Transition-Associated Mechanisms Through Regulation of Tight Junctions in Human Breast Cancer Cells
}

\author{
Javier E. Jiménez-Salazar • Pedro Posadas-Rodríguez • Roberto C. Lazzarini-Lechuga • \\ Armando Luna-López • Alejandro Zentella-Dehesa • Luis E. Gómez-Quiroz • \\ Mina Königsberg • Guadalupe Domínguez-Gómez • Pablo Damián-Matsumura
}

Received: 20 November 2013 / Accepted: 9 April 2014 / Published online: 26 April 2014

(C) Springer Science+Business Media New York 2014

\begin{abstract}
Tumor cells utilize inappropriate epithelialmesenchymal transition (EMT) mechanisms during the invasive process. It is becoming increasingly clear that estradiol (E2) induces breast cancer cell progression and enhances EMT; however, the mechanisms associated with this are unclear. We investigated the role of E2 on the expression and
\end{abstract}

\begin{abstract}
Novelty and Impact Statements We demonstrated that estrogen is able to induce tight junction (TJ) disruption in two breast cancer cell lines through the activation of c-Src. Ablated expression of the novel epithelial marker CRB3 could lead to increased cell migration. Based on our findings, we propose a novel estrogen-induced TJ pathway associated with breast cancer cell motility and, eventually, to metastasis.
\end{abstract}

Electronic supplementary material The online version of this article (doi:10.1007/s12672-014-0180-3) contains supplementary material, which is available to authorized users.

\footnotetext{
J. E. Jiménez-Salazar • R. C. Lazzarini-Lechuga •

P. Damián-Matsumura $(\triangle)$

Department of Biology of Reproduction, Universidad Autonoma

Metropolitana (UAM), 09310 Mexico City, Mexico

e-mail:pgdm@xanum.uam.mx
}

P. Damián-Matsumura

e-mail: pdmatsumura@yahoo.com

L. E. Gómez-Quiroz • M. Königsberg

Department of Health Sciences, Universidad Autonoma

Metropolitana (UAM), 09310 Mexico City, Mexico

\begin{abstract}
A. Luna-López
Department of Basic Sciences, National Institute of Geriatrics SSA, 10200 Mexico City, Mexico
\end{abstract}

\author{
A. Zentella-Dehesa \\ Department of Biochemistry, National Institute of Medical Sciences \\ and Nutrition, Salvador Zubirán (INCMNSZ), \\ 14000 Mexico City, Mexico
}

intracellular localization of the tight junction (TJ)-associated proteins, zonula occluden 1 (ZO-1), ZO-1-associated nucleic acid binding (ZONAB), and occludin, on the activation of c$\mathrm{Src}$ and human epidermal growth factor receptor 2 (HER2) expression and cellular migration in the estrogen receptor (ER)-positive breast cancer cell lines, MCF-7 and T47D. We
A. Zentella-Dehesa
Department of Genomic Medicine and Environmental Toxicology,
Universidad Nacional Autonoma De Mexico (UNAM),
04510 Mexico City, Mexico

G. Domínguez-Gómez

Sub-Direction of Clinical Research,

National Institute of Cancerology (INCan),

14080 Mexico City, Mexico

J. E. Jiménez-Salazar · P. Posadas-Rodríguez •

G. Domínguez-Gómez

Experimental Biology Graduate Program (212870),

Universidad Autonoma Metropolitana (UAM),

09310 Mexico City, Mexico 
demonstrated that $1 \mathrm{nM}$ E2 elicits c-Src activation after $15 \mathrm{~min}$. The p-Src/ZO-1 complex led to ZO-1 and ZONAB disruption at the $\mathrm{TJ}$ and increased expression of HER2 mRNAs. These changes correlate with decreased expression of the epithelial markers occludin and CRB3 and increased synthesis of N-cadherin. This led to increased MCF-7 cell migration induced by E2, even in the presence of a cell proliferation inhibitor. Incubation with ICI 182,780 (Fulvestrant), an ER antagonist, precluded the effects of E2 on c-Src phosphorylation, $\mathrm{p}-\mathrm{Src} / \mathrm{ZO}-1$ complex formation, ZO-1/ZONAB nuclear translocation, and migration of MCF7 cells. Our findings suggest that E2 promotes TJ disruption during tumor progression and increases cell motility. We propose a novel pathway where estrogens promote EMTassociated mechanisms that possibly lead to metastasis.

\section{Introduction}

Breast cancer is a major cause of cancer-related deaths for women, and its treatment is particularly difficult when metastasis occurs [1]. In many countries, deaths due to breast cancer are mostly associated with metastatic disease [2]. Epithelialmesenchymal transition (EMT) has been proposed as an essential early step in tumor metastasis and breast carcinoma progression. EMT can induce cell migration and confer invasive properties to cells, allowing them to be disseminated and reach distant organs [3]. Despite their importance, the molecular mechanisms of EMT during tumor progression are not fully understood. EMT is also known to disrupt cell-cell contact as tight junctions (TJs) disband. The loss of apicobasal cell polarity is also characteristic of EMT and permits intermingling of apical and basolateral membrane components. EMT is regulated by a complex network of signaling and gene regulatory pathways, associated with transcription factors, which result in decreased intercellular adhesion and enhanced cell migration [4]. The zonula occluden 1 (ZO-1) and the ZO-1-associated nucleic acid binding (ZONAB) proteins are among the transcription factors closely related to EMT and are components of TJs in breast epithelial cells. In addition to their roles in associating transmembrane proteins with the actin cytoskeleton, they are involved in the induction of human epidermal growth factor receptor 2 (HER2) expression [5]. HER2 is a protooncogene that is overexpressed in approximately $15 \%$ of breast cancers.

It was recently found that estrogen induces cell motility and invasion of estrogen receptor (ER)-positive breast cancer cells [6] by promoting simultaneously reversible EMT-like changes and motility [7, 8]. Despite the classical mode of action of estradiol, it has been implicated in a rapid non-genomic signaling cascade involving ER interaction with the non-receptor tyrosine kinase c-Src, which activates the phosphatidylinositol-3 kinase/Akt pathway [9]. It has also been reported that c-Src is an important adapter protein between extranuclear ERs and HER2, allowing for cross talk pathways in cancer cell lines [10].

It has been demonstrated that high expression and/or activation of c-Src can promote EMT associated with breast cancer cell invasion [11]. As shown by Hsia et al. [12], a probable mechanism by which cSrc promotes invasive behavior is through formation of a transient complex with focal adhesion kinase (FAK), another protein tyrosine kinase [12]. Some evidence suggests that $\mathrm{TJ}$ protein phosphorylation plays an important role in the regulation of cell-cell adhesion [13, 14]. It is worth noting that occludin and CRB3, intercellular binding proteins, have been used as epithelial and polarity markers in EMT studies $[15,16]$. In our study, to understand the complex process of tumor progression, we attempted to demonstrate that estradiol induces EMT-associated mechanisms, including c-Src phosphorylation, $\mathrm{p}$-Src/ZO-1 complex formation, ZO-1/ZONAB nuclear translocation, increased permeability, downregulation of occludin and CRB3 expression, increased $\mathrm{N}$-cadherin expression, and motility of breast cancer cells, through a novel pathway involving TJ proteins.

\section{Materials and Methods}

\section{Reagents}

Dulbecco's modified Eagle's medium (DMEM), antibiotics, and antimycotics were purchased from Life Technologies (Gaithersburg, MD). Fetal bovine serum (FBS) was purchased from Gibco BRL (Gaithersburg, MD). The RNA extraction kit RNeasy ${ }^{\circledR}$ was purchased from Qiagen (Valencia, CA). Reverse transcription and polymerase chain reaction (PCR) reagents were purchased from Promega (Madison, WI). Bradford reagent was purchased from BioRad (Hercules CA). $17 \beta$-Estradiol and cytosine $\beta$-D-arabinofuranoside hydrochloride, a selective inhibitor of DNA synthesis that does not inhibit RNA synthesis, were purchased from Sigma-Aldrich (Saint Louis, MO). The ER antagonist ICI 182,780 was purchased from Tocris (Ballwin, MO). Antibodies against cSrc (SC-5266), p-cSrc (SC-81521), CRB3 (SC-27901), histone H1 (SC-10806), occludin (SC-81812), ZO-1 (SC-10804), and MSY3/4(F19) (SC21318) were purchased from Santa Cruz Biotechnology (Santa Cruz, CA). Antibodies against HER2/ErbB2 (D8F12/4290P) were obtained from Cell Signaling Technology (Beverley, MA, USA). All reagents we used were of the highest purity available.

\section{Cell Culture}

We used MCF-7 and T47D human breast cancer cell lines that are positive to ER $\alpha, \mathrm{ER} \beta$, and HER2. MCF-7 cells were obtained from the American Type Culture Collection (ATCC, 
Manassas, VA), and T47D was kindly provided by Dr. Juan Pedro Luna Arias (CINVESTAV, Mexico City, Mexico). Cell cultures were seeded at a density of $150,000 \mathrm{cells} / \mathrm{cm}^{2}$ in DMEM containing $10 \%$ FBS (Gibco BRL), $100 \mathrm{U} / \mathrm{mL}$ penicillin, and $100 \mathrm{mg} / \mathrm{mL}$ streptomycin (Life Technologies, Inc). Cultures were incubated at $37{ }^{\circ} \mathrm{C} / 5 \% \mathrm{CO}_{2}$. For hormonal treatments, cells were cultured in phenol red-free DMEM containing $2.5 \%$ FBS that was previously treated with charcoal-dextran (FBS-C). Cells were treated with vehicle (0.1\% ethanol), ICI 182,780 (100 nM), cycloheximide (CHX; $12.5 \mu \mathrm{g} / \mathrm{mL})$, or $17 \beta$-estradiol $(1 \mathrm{nM})$ for $0,0.25$, $0.5,1,3,6,9,24$, and $48 \mathrm{~h}$.

\section{Immunoblotting}

Western immunoblotting was conducted as previously described [13]. Whole cell lysates were prepared using lysis buffer (50 mM Tris- $\mathrm{HCl} \mathrm{pH}$ 8.0, $120 \mathrm{mM} \mathrm{NaCl}, 0.5 \% \mathrm{NP}-$ 40, $100 \mathrm{mM} \mathrm{NaF}, 0.2 \mathrm{mM} \mathrm{NaVO}_{3}, 1 \mu \mathrm{g} / \mathrm{mL}$ aprotinin, $1 \mathrm{mM}$ phenylmethylsulfonyl fluoride, $1 \mu \mathrm{g} / \mathrm{mL}$ leupeptin). Cell homogenates were incubated at $4{ }^{\circ} \mathrm{C}$ for $5-10 \mathrm{~min}$ and centrifuged $\left(22,000 \times g, 4^{\circ} \mathrm{C}, 20 \mathrm{~min}\right)$. The concentration of proteins in the supernatant was determined by using the Bradford reagent (Bio-Rad). Whole cell lysates were separated by $10 \%$ sodium dodecyl sulfate polyacrylamide gel electrophoresis (SDS-PAGE) and transferred to polyvinylidene difluoride (PVDF) membranes (Invitrogen/Life Technologies). Membranes were probed with antibodies against $\mathrm{ZO}-$ 1, ZONAB, occludin, c-Src, p-Src (Tyr 416), CRB3, Ncadherin, or HER-2 (1:1,000 dilution), at $4^{\circ} \mathrm{C}$, overnight. Membranes were then washed three times with Tris-buffered saline (TBS) supplemented with Tween 20 (TBS-T) and incubated with an appropriate horseradish peroxidase (HRP)conjugated secondary antibody (Pierce, Rockford, IL) for $1 \mathrm{~h}$ at room temperature. Immunoreactive bands were visualized with ECL-Plus Western Blotting Detection Reagents (GE Healthcare).

Immunoprecipitation (IP) Assays

We conducted IP assays as previously reported by ClavijoCornejo [17]. Briefly, $2 \mathrm{mg}$ of whole cell lysate was incubated with antibodies against p-Src or ZO-1 according to the manufacturer's instructions. Subsequently, $40 \mu \mathrm{L}$ of protein $\mathrm{A} /$ agarose (1:1) was added and gently rocked overnight at $4{ }^{\circ} \mathrm{C}$, and the was mixture then centrifuged $(12,000 \times g$, $5 \mathrm{~min}, 4^{\circ} \mathrm{C}$ ). The supernatant was removed and precipitates were washed with $500 \mathrm{~mL}$ of lysis buffer. Immunoprecipitated proteins were separated by $10 \%$ SDS-PAGE and transferred to PVDF membranes which were blocked with $5 \%(w / v)$ skim milk in phosphate-buffered saline (PBS) containing Tween 20 (PBS-T). Membranes were probed with antibodies against $\mathrm{p}$ Src and ZO-1.
Immunofluorescence Assays

Treated MCF-7 and T47D cells were fixed with $4 \%$ paraformaldehyde in PBS. Samples were permeabilized with $0.01 \%$ $(v / v)$ Triton-X 100 for $30 \mathrm{~min}$ and blocked with $3 \%(w / v)$ bovine serum albumin (BSA) in PBS for 30 min and subsequently incubated with primary antibodies (1:100). The corresponding secondary antibodies were fluorescein isothiocyanate (FITC)-conjugated anti-rabbit (1:200), Texas Redconjugated anti-mouse $(1: 200)$, and rhodamine-conjugated anti-goat (1:200). Nuclei were counterstained with $1 \mu \mathrm{g} / \mathrm{mL}$ 4',6-diamidino-2-phenylindole (DAPI) (Sigma-Aldrich). Images were obtained using a multi-photon confocal microscope (Carl Zeiss LSM-780 NLO).

\section{Phalloidin Staining}

Cells were grown to $100 \%$ confluence and fixed with $4 \%$ paraformaldehyde in PBS. Cells were then permeabilized with $0.01 \%(v / v)$ Triton-X 100 for $30 \mathrm{~min}$. Blocking was performed with $3 \%(w / v)$ BSA in PBS for $30 \mathrm{~min}$. For filamentous actin staining, fixed and permeabilized cells were incubated with $40 \mu \mathrm{M}$ phalloidin (Alexa Fluor 488, Life Technologies) in PBS for $30 \mathrm{~min}$ at room temperature. Nuclei were counterstained with $1 \mu \mathrm{g} / \mathrm{mL}$ DAPI (Sigma-Aldrich). Images were obtained using a multi-photon confocal microscope (Carl Zeiss LSM-780 NLO).

Subcellular Localization of TJ Proteins

MCF-7 cells were treated with $1 \mathrm{nM}$ estradiol (E2) for 15, 30, and $60 \mathrm{~min}$. After treatment, nuclear and cytoplasmic proteins were isolated as previously reported by Clavijo-Cornejo [17].

\section{Total RNA Isolation and Reverse Transcription PCR} (RT-PCR)

Total RNA was isolated from MCF-7 cells using an RNeasy Mini Kit (Qiagen), according to the manufacturer's instructions. We conducted RT-PCR assays using a one-step RT-PCR kit (Promega). We designed specific oligonucleotide primers with Primer Quest software. Primers were specific for the amplification of ZO-1 (sense, 5'-ATGGTGCGCTGAAAGA AG CA-3'; antisense 5'-AATTGGTTGTGGCTGCGC TT-3'), ZONAB (sense, 5'-TGCAGAAGCTGCCAATGT GA-3'; antisense, 5'-ATGAACCGGTCCCTGAAG TT-3'), occludin (sense, 5'-TTTCATTGCCGCGTTGGT GA-3'; antisense, 5'TACAATGGCAATGGCCTC CT-3'), and HER2 (sense, 5'GTG GGG CGC CCC A GG CAC CA-3'; antisense, 5'-CTT AAT GTC ACG CAC GAT TTC-3') fragments. We reported expression levels that were relative to the expression level of the reference gene $\beta$-actin (sense, 5'-GTG GGG CGC CCC 
AGG CAC CA-3'; antisense, 5'-CTT AAT GTC ACG CAC GAT TTC-3').

\section{Wound Healing Assays}

As reported by Sanchez et al. [6], MCF-7 cells were grown to $100 \%$ confluence. Cells were maintained in culture medium for $24 \mathrm{~h}$ before "wounding" (scratching), and then treatments (Vh, $1 \mathrm{nM}$ E2 or $1 \mathrm{nM} \mathrm{E2}+100 \mathrm{nM}$ ICI 182,780) were supplemented to wells during $4,12,24$, or $48 \mathrm{~h}$. Linear scratches (approximately $0.7-\mathrm{mm}$ wide) were gently made with a sterile pipette tip across the culture surface; wells were then rinsed with PBS to remove debris. In order to show that wound healing is due to cell migration instead of E2-induced cell proliferation, cells were also incubated in the absence and presence of $100 \mu \mathrm{M}$ cytosine $\beta$-D-arabinofuranoside hydrochloride, a DNA synthesis inhibitor, at $48 \mathrm{~h}$ of E2 incubation. For each condition, at least five pictures were taken with an inverted microscope (Carl Zeiss Axiovert $40 \mathrm{CFL}$ ) at 0, 4, 12, 24 , and $48 \mathrm{~h}$ after scratching. The proportion of unrecovered wound area was calculated by dividing the unrecovered area after hormone treatment with the initial wound area at $0 \mathrm{~h}$.

\section{Statistical Analysis}

We presented data as mean $\pm \mathrm{SD}$ for at least three independent experiments carried out in triplicate. We used GraphPad Prism Software to conduct Student's $t$ test or ANOVA, as appropriate. Comparisons between groups were carried out using the Tukey-Kramer multiple comparison test. Differences were considered significant when $P$ values were less than 0.05 .

\section{Results}

E2 Induces c-Src Phosphorylation and p-Src/ZO-1 Complex Formation

Phosphorylation of $\mathrm{Tyr}^{416} \mathrm{c}-\mathrm{Src}(\mathrm{p}-\mathrm{Src})$ is involved in the highest activity of this enzyme; therefore, the effect of E2 on c-Src activation was tested in MCF-7 breast cancer cells. We observed a rapid 1.6-fold increase in p-Src levels after $15 \mathrm{~min}$ of incubation with $1 \mathrm{nM} \mathrm{E2}$ (Fig. 1a); this was ablated by the addition of $100 \mathrm{nM}$ of ICI 182,780. p-Src levels decreased after 30 and $60 \mathrm{~min}$ to those observed in vehicle-treated cells. Actin and total immunoreactive c-Src (total Src) levels were unchanged over the experimental period (Supplementary Fig. 1; S1).

To ascertain the effect of estradiol in the formation of the Src/ZO-1 complex in two ER-positive breast cancer cell lines, MCF-7 and T47D, immunoprecipitation assays were performed. Our IP assay results revealed that a 15-min exposure to $1 \mathrm{nM}$ of $\mathrm{E} 2$ led to an increase in $\mathrm{Tyr}^{416} \mathrm{p}$-Src/ZO-1 complex formation; this interaction was disrupted by ICI 182,780 . The E2-dependent binding of p-Src to ZO-1 was observed in MCF-7 cells and, to a lesser extent, in T47D cells as compared with vehicle-treated cells (Fig. 1b). MCF-7 cells were used to study the subcellular localization of p-Src/ZO-1 complexes after a 15-min E2 incubation (Fig. 1c), and these were clearly observed at the plasma membrane. As expected, complex formation was disrupted when ICI 182,780 was used.

\section{E2 Disrupts ZO-1 and ZONAB and Induces Nuclear Localization}

In order to show that the E2-induced c-Src activation triggers ZO-1 and ZONAB translocation to the nucleus, changes in the localization of those proteins were performed by Western blot and immunolocalization assays. Treatment of MCF-7 cells with $1 \mathrm{nM}$ E2 led to rapid ZO-1 and ZONAB nuclear translocation at $15 \mathrm{~min}$ of treatment. This translocation peaked at $60 \mathrm{~min}$ for ZO-1 (Fig. 2a) and 30 min for ZONAB (Fig. 2a); cytoplasmic content of each protein was diminished accordingly.

To confirm the effects of E2 on ZO-1 and ZONAB translocation, MCF-7 (Fig. 2c) and T47D (Fig. 2d) cells were used to visualize changes in subcellular localization of $\mathrm{ZO}-1$ and ZONAB. Both breast cancer cell lines, grown to $100 \%$ confluence and treated $1 \mathrm{~h}$ with $1 \mathrm{nM} \mathrm{E2}$, exhibited membrane translocation of both ZO-1 and ZONAB proteins. Areas of colocalization inside the nuclei are clearly observed, particularly in MCF-7 cells. Consistent with the immunoblotting results, ICI 182,780 abrogated estrogen-induced ZO-1 and ZONAB translocation.

To further confirm TJ protein colocalization inside the nuclei of MCF-7 cells, we conducted a 3D reconstruction using confocal microscopy Zen software (LSM-780 NLO, Carl Zeiss) and Z-stack image capturing. We found that E2 induces nuclear localization of both TJ proteins (Supplementary Video 1; SV1), and vehicle treatment did not induce this effect (Supplementary Video 2; SV2).

E2 Regulates HER2 Expression by a Mechanism Independent of De Novo Protein Synthesis

We observed that HER 2 mRNA levels increased ( $>70 \%)$ at $3 \mathrm{~h}$ posttreatment with either 1 or $100 \mathrm{nM}$ of E2 (Fig. 3a, b). Thereafter, HER2 expression was decreased even below the levels observed for vehicle-treated controls after longer periods of incubation $(6-24 \mathrm{~h})$. Similar results were observed when MCF-7 cells were incubated with either low or high E2 concentrations. Two concentrations of E2 were used because it has been reported that $\mathrm{E} 2$ can modulate HER2 expression in MCF-7 cells after short incubation periods, depending on E2 concentration [18-22].

To demonstrate that increased expression levels of E2induced HER2 were due to preexistent ZO-1 and ZONAB 
a

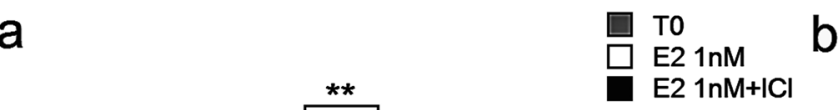

b

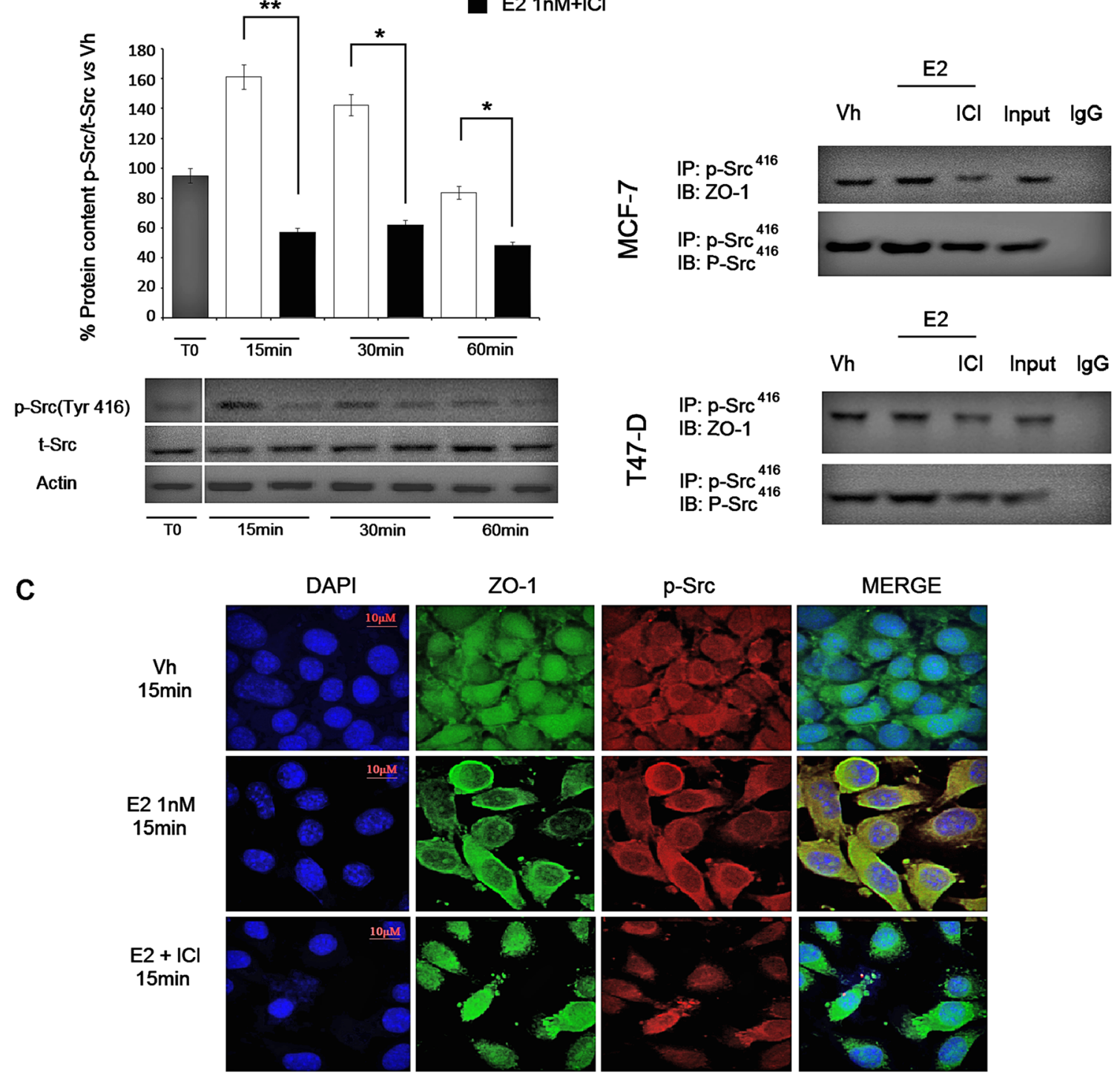

Fig. 1 E2 activates c-Src and induces rapid formation of p-Src/ZO-1 complex in human breast cancer cells. a In MCF-7 cells, E2 (1 nM) induced a significant increase in the phosphorylation of c-Src at ${ }^{416} \mathrm{Tyr}$ after 15 to $30 \mathrm{~min}$ of incubation (white bars), an effect that was precluded by the use of the ER antagonist ICI $(1 \mu \mathrm{M}$; black bars $)$ to values below to the initial time, where no ethanol was added (TO; gray bar). Phospho$\mathrm{Src}^{416}(p-S r c)$ densitometry values were adjusted to total $\mathrm{Src}(t-S r c)$ intensity and then normalized to vehicle $(V h)$, as $100 \%$. ${ }^{*} P<0.05$ vs. $\mathrm{E} 2+\mathrm{ICI}$ and $* * P<0.01$ vs. E2 + ICI. b MCF-7 or T47D cell proteins were co-immunoprecipitated $(I P)$ with antibodies against $\mathrm{p}-\mathrm{Src}^{416}$ and

proteins of the TJ, MCF-7 cells were co-incubated with E2 and CHX. We did not observe differences in HER2 mRNA expression levels in the absence and presence of $\mathrm{CHX}$, with 1 or $100 \mathrm{nM}$ E2 (Fig. 3a, b) between 0.25 and $9 \mathrm{~h}$ of incubation, except at $24 \mathrm{~h}$. At this point, HER2 mRNA levels were increased up to $250 \%$ compared with CHXfree treatments. Immunolabeled HER2 proteins could be seen in the cytoplasm only after $24 \mathrm{~h}$ of E2 + CHX
$\mathrm{ZO}-1$, in the absence and presence of $1 \mathrm{nM}$ of E2 for $15 \mathrm{~min}$, with or without ICI. The membranes were re-blotted for the immunoprecipitated protein to show equal input (left lane). Representative images of at least three independent experiments are shown. c MCF-7 cells were stained with anti-phosphor-Src and observed under confocal microscopy after 15 min of incubation with vehicle or E2, in the absences and presence of ICI. Secondary fluorescent antibodies were FITC (green) and Texas Red (red) for ZO-1 and p-Src, respectively. Nuclei were counterstained with DAPI (blue). Double staining (yellow signal) highlights areas of colocalization

incubation and additional $24 \mathrm{~h}$ with CHX-free media (24/ $24 \mathrm{~h}$ in Supplementary Fig. 2; S2).

TJ Protein Expression Is Regulated by E2

E2 significantly increased ZO-1 (Fig. 4a, b) and ZONAB (Fig. 4c, d) mRNA and protein expression levels after 6 and $9 \mathrm{~h}$ of E2 incubation, respectively. The mRNA levels were 


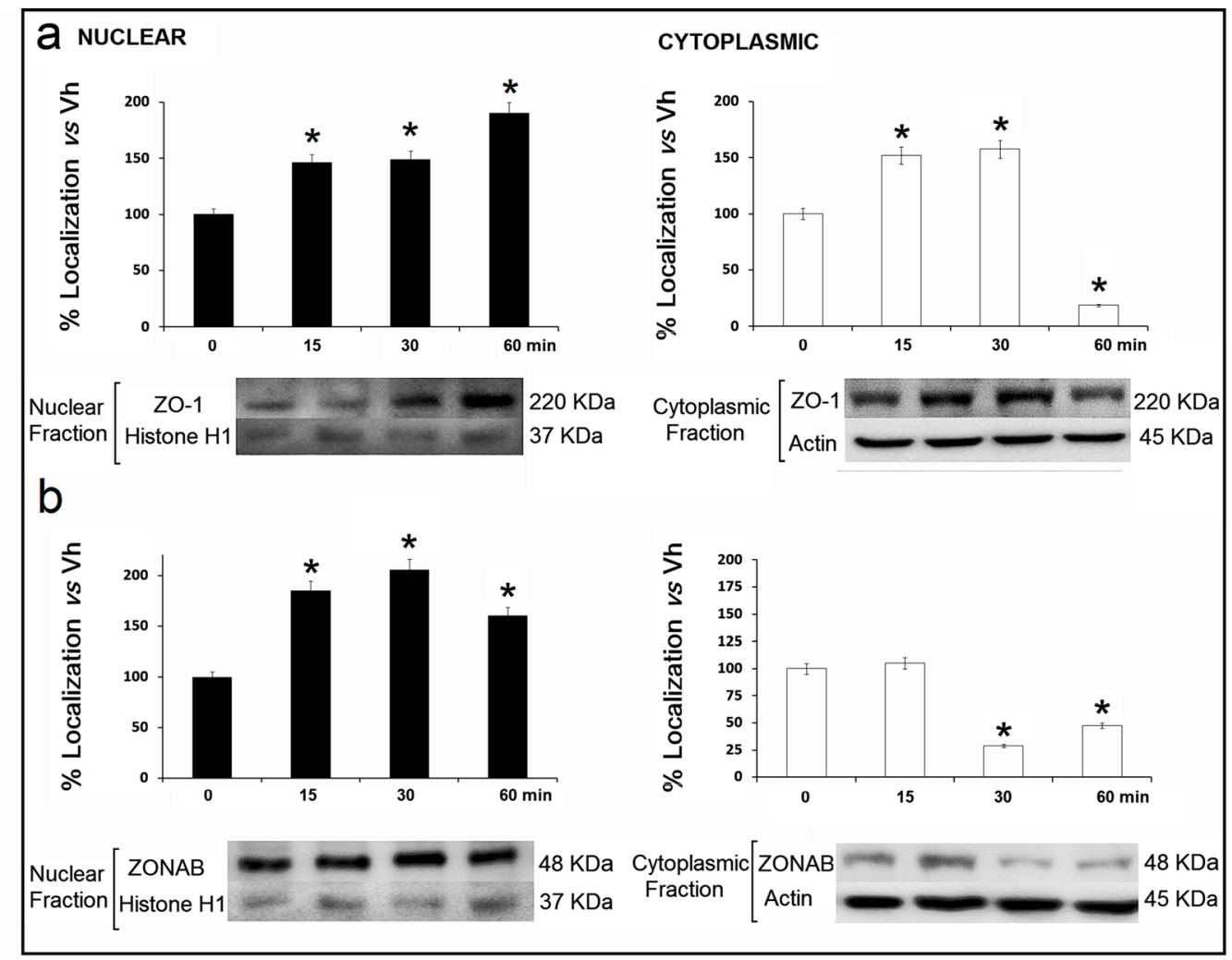

\section{MCF7}

C

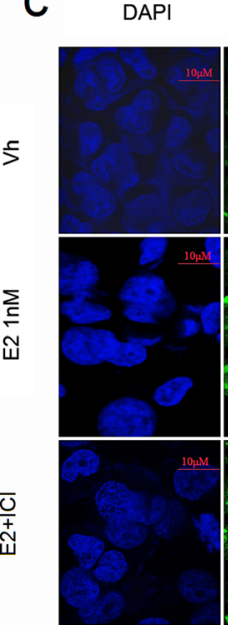

ZO-1

ZONAB
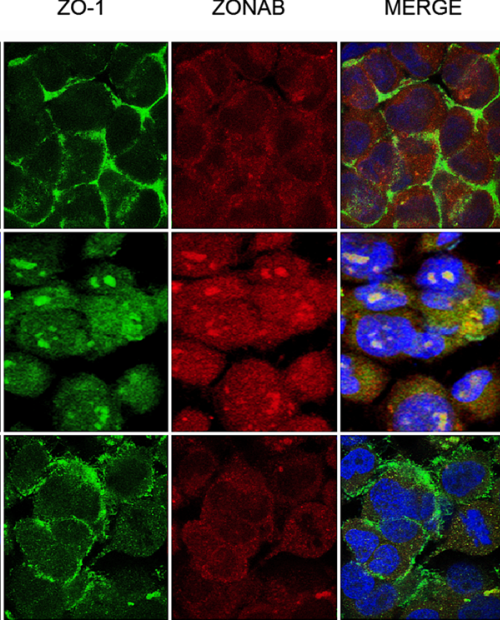

Fig. 2 Nuclear translocation of ZO-1 and ZONAB is induced by E2. Changes in the intracellular localization of ZO-1 (a) and ZONAB (b) proteins were observed when MCF-7 cells were incubated during $1 \mathrm{~h}$, with $1 \mathrm{nM}$ of E2. Signal intensities were quantified, normalized with actin (cytoplasmic fractions; white bars) or histone $\mathrm{H} 1$ (nuclear fractions; black bars), and expressed as percent of control groups ( $\mathrm{Vh}$; ethanol). In order to show that both ZO-1 and ZONAB proteins are colocalized inside the nuclei, confocal fluorescence digital images were taken in high confluence MCF-7 cells, when incubated with vehicle, E2 alone, or E2 + ICI

increased up to $200 \%$ after 15 and 30 min of 22 incubation for ZO-1 and ZONAB, respectively; protein levels were increased after $9 \mathrm{~h}$. In contrast, occludin mRNA and protein

\section{T47D}

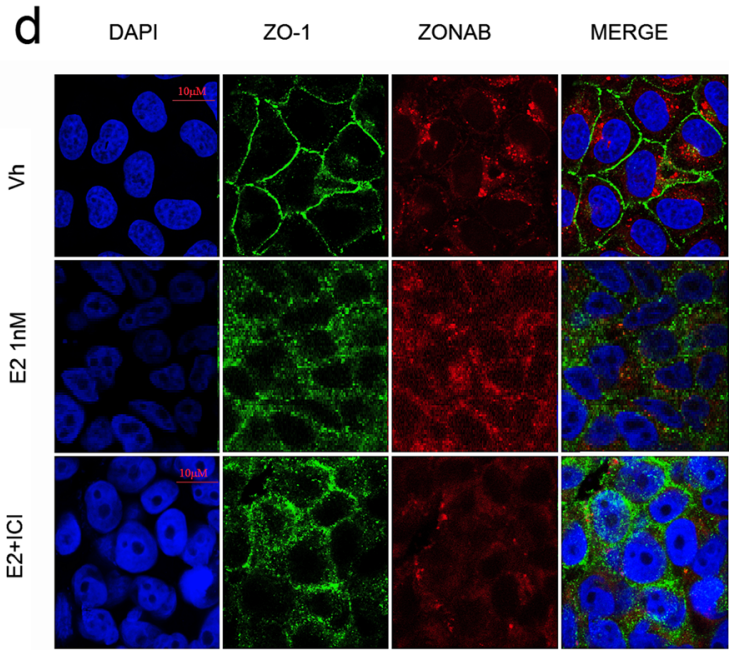

(ER antagonist). E2 incubation decreases membrane localization of both proteins and increases their concentration inside the nuclei, an effect that was totally precluded by the incubation with ICI. In order to demonstrate nuclear colocalization of ZO-1 (FITC, green labeled) and ZONAB (rhodamine; red labeled), MCF-7 (c) or T47D (d) cancer cells were grown in high confluence and incubated in the absence and presence of $1 \mathrm{nM}$ of E2. All images are representative of at least three different experiments. Original magnifications $\times 400$

levels were decreased by 40 and $60 \%$, respectively, when MCF-7 cells were incubated with $1 \mathrm{nM}$ E2 for $24 \mathrm{~h}$ (Fig. 4e, f). 
Fig. 3 HER2 expression increased by short-time incubation with $\mathrm{E} 2$, independently of de novo protein synthesis. HER2 mRNA levels were measured in 0.25 -h intervals and 3, 6, 9 or $24 \mathrm{~h}$ of incubation with low $(1 \mathrm{nM}$; a) or high $(100 \mathrm{nM}$; b) E2 concentrations (white bars). At $3 \mathrm{~h}$ of incubation with $1 \mathrm{nM}$ E2, HER2 mRNA levels increased up to twofold in the absence and presence of the de novo protein inhibitor cycloheximide ( $\mathrm{CHX}$; $12.5 \mu \mathrm{g} / \mathrm{ml}$, black bars) and decreased at $6 \mathrm{~h}$ of $\mathrm{E} 2$ incubation. Long-time incubations (9-24 h) with E2 increased HER2 mRNA, an effect that depended on de novo protein synthesis. There were no differences between low and high concentrations of E2. Results are expressed as percent of HER2/actin vs. control $(\mathrm{Vh})$ cells (mean \pm SD). $* P<0.05$ vs. control. Representative images of at least three independent experiments are shown a TO

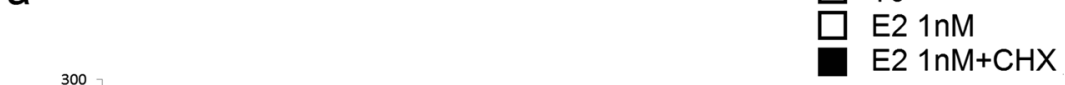

b
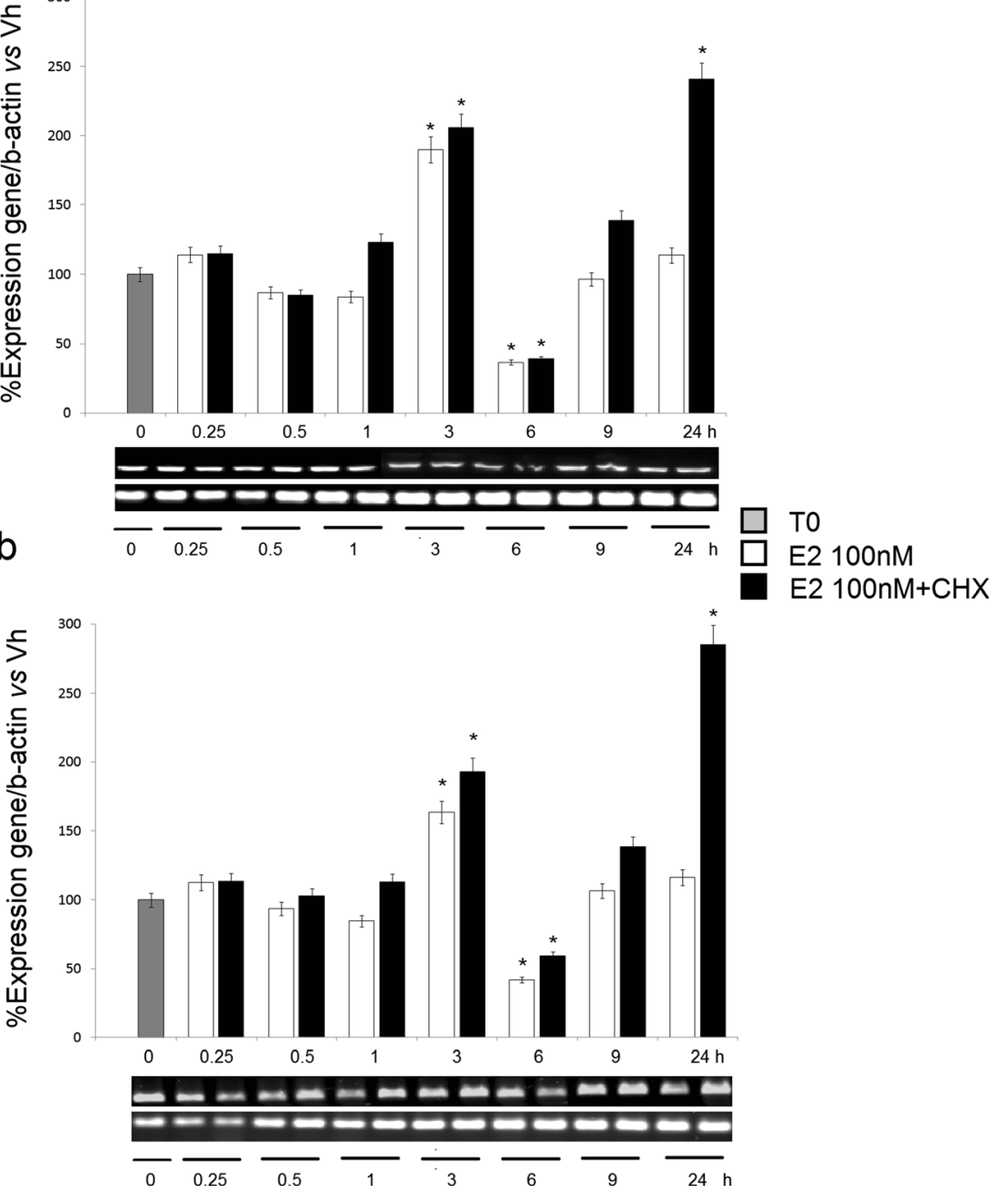

Estrogen Induces Changes in Epithelial and Mesenchymal Markers

It has been demonstrated that EMT is necessary for breast epithelial cancer cell tumor progression, including changes in cell morphology, loss or low expression of epithelial markers (e.g., E-cadherin, CRB3, occludin, etc.), and acquisition of mesenchymal markers (e.g., N-cadherin, vimentin, fibronectin, etc.) [23]. Thus, we evaluated the effects of E2 on CRB3 (a novel apical marker that plays a key role in tight junction regulation in different epithelial cells; Fig. 5a) and N-cadherin (Fig. 5b) expression. Unexpectedly, we observed that E2 increased CRB3 levels by 2.4 -fold after $24 \mathrm{~h}$; however, this rapidly decreased to $50 \%$ compared with vehicle-treated cells after $96 \mathrm{~h}$. E2 progressively increased N-cadherin levels 3.2fold after 48-96 h, peaking at $72 \mathrm{~h}$. Immunofluorescent detection revealed the presence of $\mathrm{CRB} 3$ and $\mathrm{N}$-cadherin at the MCF-7 cell membrane (Fig. 5c).

\section{E2 Promotes MCF-7 Migration In Vitro}

We found that E2 modifies cell morphology and motility (Fig. 6a). Confluent monolayers of MCF-7 cells were wounded and incubated with vehicle, $1 \mathrm{nM}$ E2 or $1 \mathrm{nM}$ $\mathrm{E} 2$, and $100 \mathrm{nM}$ ICI $182,780(100 \mathrm{nM})$ and the amount of wound repair was determined (Fig. 6b). At $48 \mathrm{~h}$, in the presence of E2, repair of the wounded cell culture was significantly accelerated $(P<0.001)$. To show that wound repair was due to cell migration instead of cell proliferation, MCF-7 cells were incubated in the presence of $100 \mu \mathrm{M}$ cytosine $\beta$-D-arabinofuranoside hydrochloride at $48 \mathrm{~h}$ after the addition of E2. Similar results were observed in the absence and presence of the DNA synthesis inhibitor (I).

Taking together, we propose that during the incubation period, breast cancer cells moved forward and closed the gap; this effect was independent of cell division, as shown in 
a

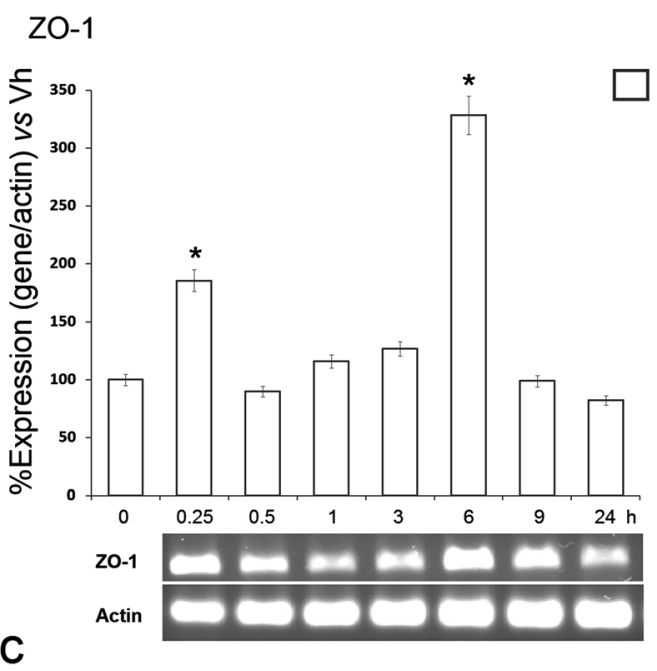

\section{ZONAB}

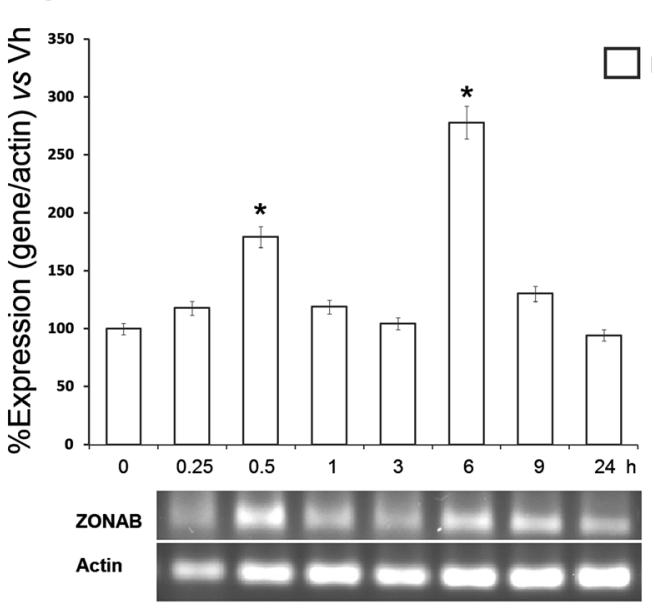

e

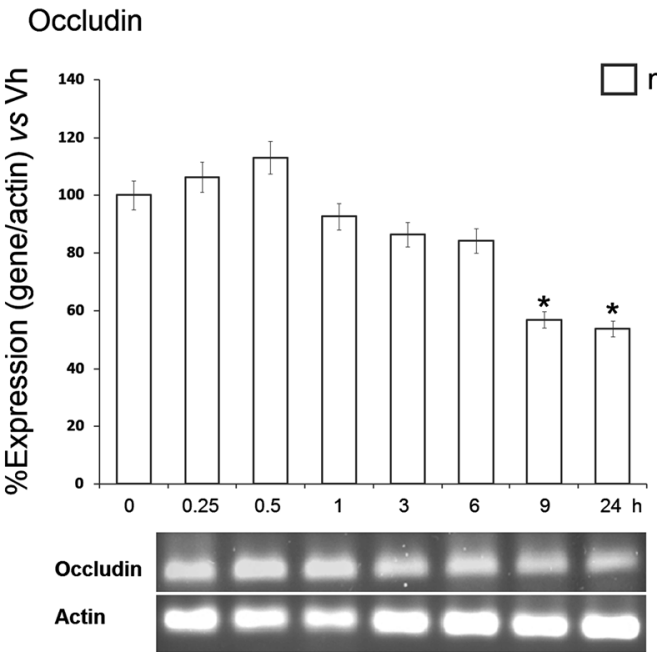

Fig. 4 a-f Effects of E2 on ZO-1, ZONAB, and occludin expression in MCF-7 cells. E2 induced a time-dependent effect on tight junction proteins ZO-1 (a, b), ZONAB (c, d), and occludin (e, f), as measured by their mRNA (white bars) or protein (black bars), in short (15-60 min) and long (6-24 h) time intervals. Maximal increases in ZO-1 and ZONAB expression were b
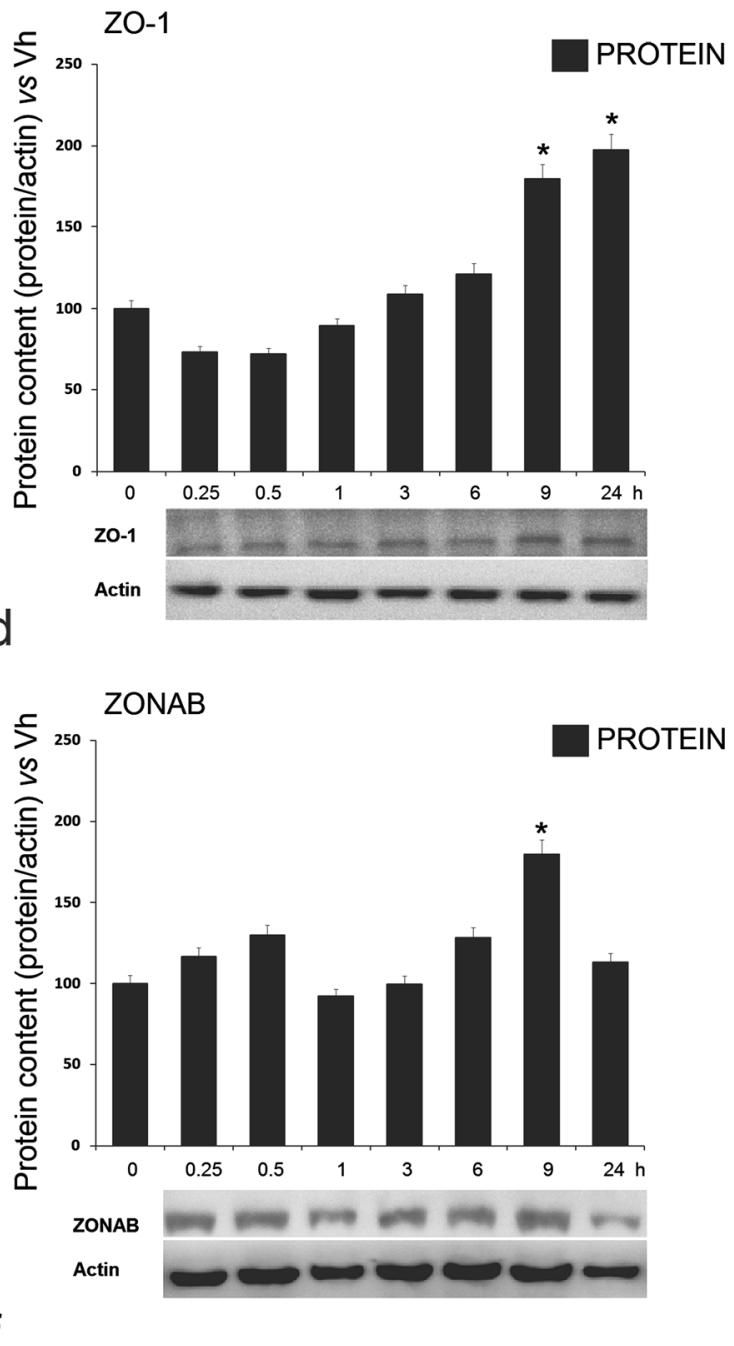

Occludin

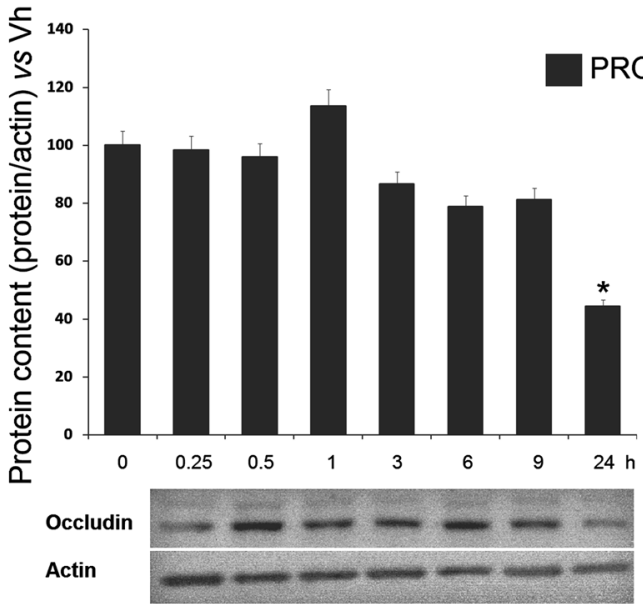

observed after $6 \mathrm{~h}$ (mRNA) and $9 \mathrm{~h}$ (protein) of incubation with E2. Opposite effect was observed with occludin expression that decreased after 9-12 h of E2 $(1 \mathrm{nM})$ incubation. Results are expressed as percentage of ZO-1, ZONAB or occludin/actin vs. vehicle $(\mathrm{Vh})$, as $100 \%$, and representative experiments are presented. Values are the mean $\pm \mathrm{SD}$ of three separate experiments. ${ }^{*} P<0.05$ 
other studies [24]. We analyzed phenotypical changes around the wound area, including wound shape, MCF-7 cell morphology, intercellular separation, formation of pseudopodia, and cytoskeletal dynamics of F-actin (Fig. 6c). We observed that E2 increased filopodia formation, and cells were interconnected by cytoplasmic extensions compared with vehicle-treated control cells, at $48 \mathrm{~h}$, as observed in the $\times 3$ magnification.

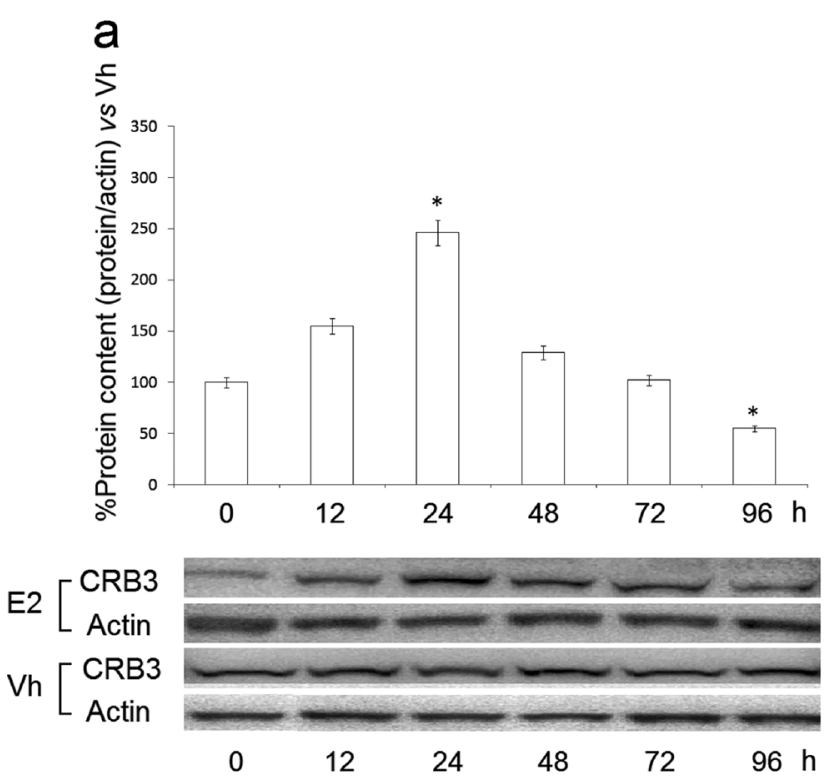

C

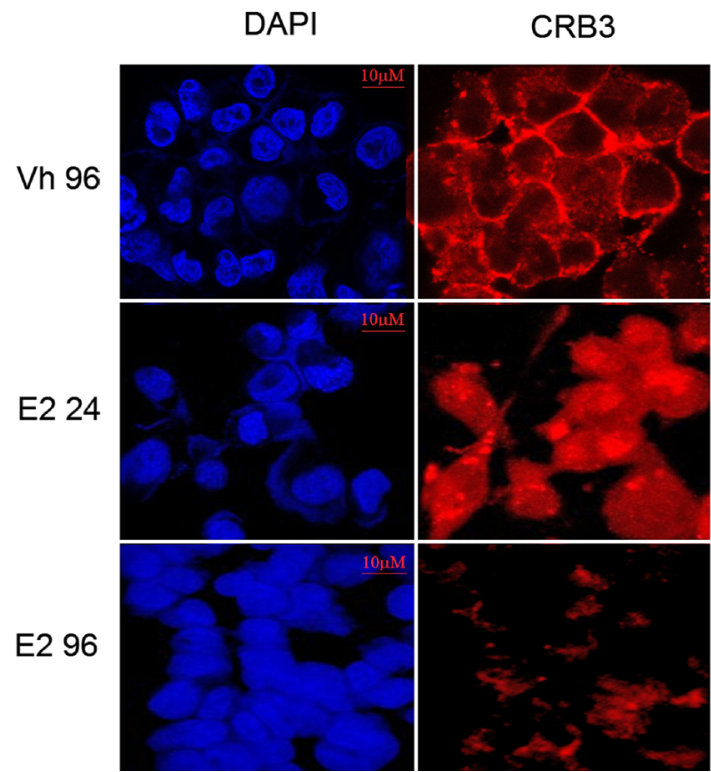

Fig. 5 Effect of E2 on CRB3 and N-cadherin expression. MCF-7 breast cancer cells were incubated with $1 \mathrm{nM}$ of E2, during 12 to $96 \mathrm{~h}$, and expression of the epithelial cell marker protein CRB3 (a) or the mesenchymal cell marker protein $\mathrm{N}$-cadherin (b) was measured by Western blot analysis and compared to ethanol-treated cells $(V h)$. The incubation with E2 on CRB3 protein expression showed a biphasical effect, since CRB3 concentration increased at $24 \mathrm{~h}$ and decreased between 48 and $96 \mathrm{~h}$ of incubation. Results are expressed as percent of CRB3/actin or N-cadherin/

\section{Discussion}

It is well known that estrogens have an important role in motility, invasion, and distant metastasis of breast cancer cells $[25,26]$. The effect of these hormones on EMT [27-29] is known; however, the mechanism(s) through which estrogens promote this process remain unclear. We were able to demonstrate that estrogen promotes TJ disruption, HER2
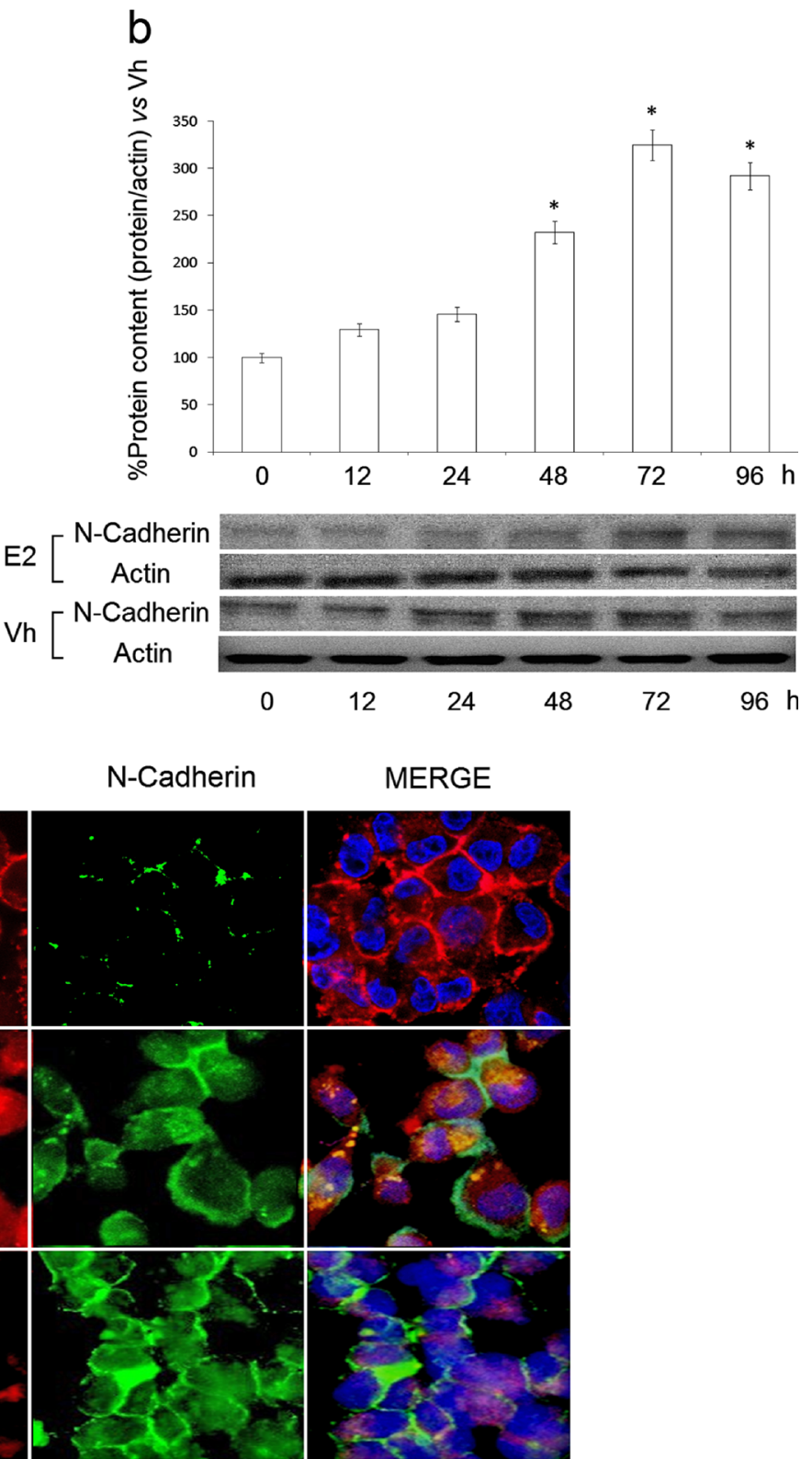

actin vs. control (Vh) cells (mean $\pm \mathrm{SD}$ ). ${ }^{*} P<0.05$ vs. control. Representative images of at least three independent experiments are shown. $\mathbf{c}$ MCF-7 cells were cultivated at high confluence and thereafter incubated with either vehicle or E2 $(1 \mathrm{nM})$ for 24 or $96 \mathrm{~h}$. Both proteins were visualized by confocal microscopy and images were processed. CRB3 protein expression (red labeled; rhodamine) lowered at MCF-7 cell membranes (24 h) and almost vanished ( $96 \mathrm{~h}$ ); on the other hand, $\mathrm{N}$-cadherin expression (green labeled; FITC) gradually became more intense at cell membranes 

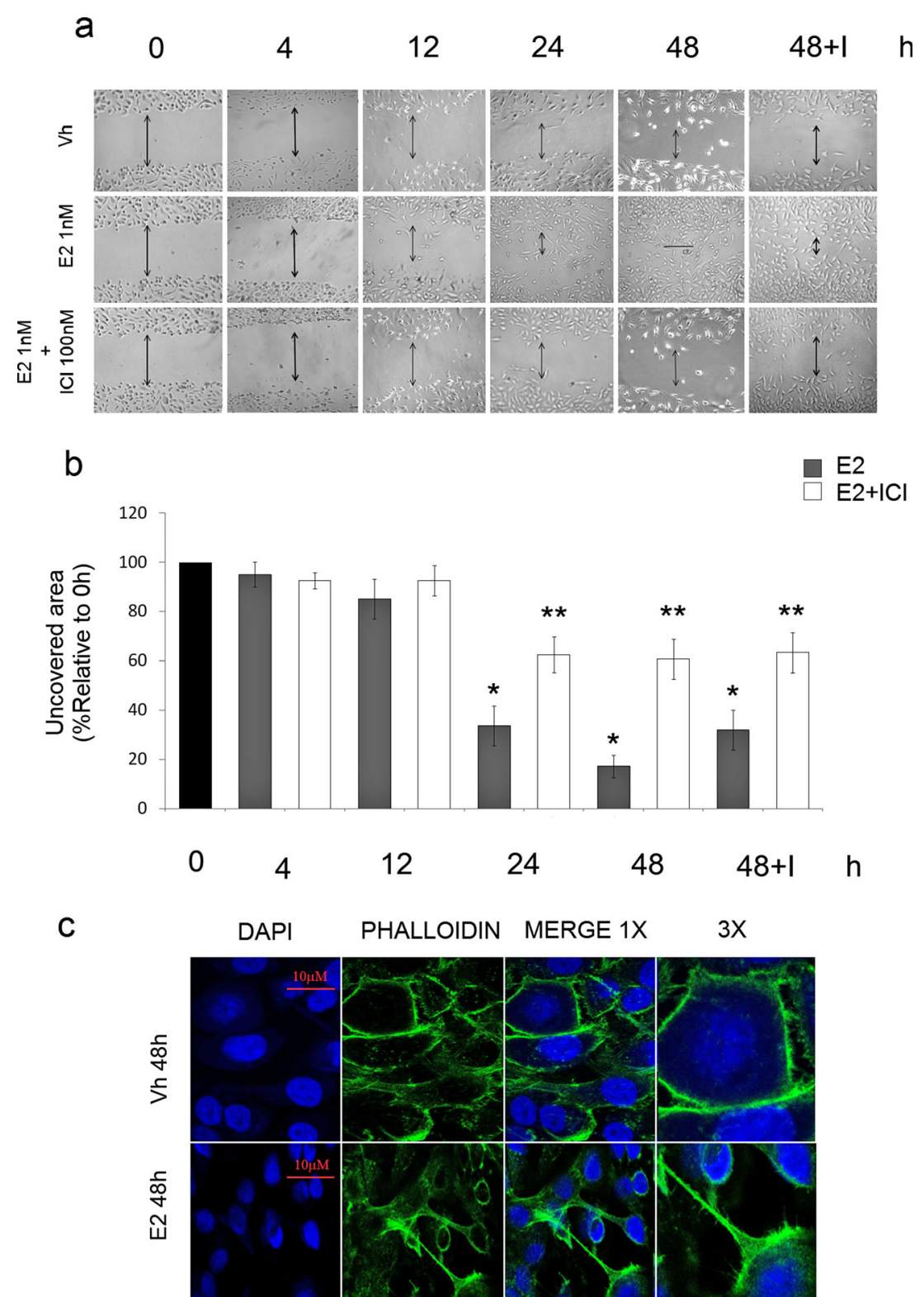

Fig. $6 \mathrm{MCF}-7$ breast cancer cells are induced by E2 to undergo cell migration. a Confluent monolayers of MCF-7 cells were wounded with a uniform scratch, washed to remove cell debris, and cultured during 0,4 , 12,24 , or $48 \mathrm{~h}$ of incubation with vehicle $(\mathrm{Vh}), 1 \mathrm{nM}$ of E2, or E2 + ICI $(100 \mathrm{mM})$. In order to demonstrate that wound healing is not due to the growth of MCF-7 cells stimulated by estradiol, 48-h experiments were performed in the absence and presence of the selective inhibitor (I) of DNA synthesis cytosine $\beta$-D-arabinofuranoside hydrochloride $(10 \mu \mathrm{M})$. Images of cell cultures were captured at $0,4,12,24$, or $48 \mathrm{~h}$ after scratching. Representative pictures are shown; original magnification, $\times 40$. The arrow indicates the wound edge. $\mathbf{b}$ The amount of wound repair

upregulation (probably due to ZO-1/ZONB nuclear translocation), and increases cell motility in breast cancer cell lines. We showed that estrogen rapidly induces c-Src activation via phosphorylation of Tyr 416, leading to the formation of the p-Src/ZO-1 complex at the cell membrane. This finding was consistent with previous reports showing that, in addition to its nuclear functions, ER also participates in extranuclear was expressed as uncovered area at the indicated time compared with initial uncovered area of vehicle-treated control at time zero. Values are the mean $\pm \mathrm{SD}$ of three separate experiments. ${ }^{*} P<0.001$ compared with control. c Effect of E2 on MCF-7 cell migration was analyzed by the cytoskeletal dynamics of F-actin, labeled with green phalloidin, showing that E2 increases filopodium formation as compared with 48-h vehicletreated control MCF-7 cells in confluent monolayers. This E2 effect was precluded by the incubation with $100 \mathrm{nM}$ of ICI of MCF-7. Nuclei were counterstained with DAPI (blue). Higher magnification $(\times 3)$ is used to highlight filopodium formation

signaling events [30]. These events include the binding of ER beta to c-Src in prostate cancer cells [31]; the ER-Src axis constitutes a critical pathway used by breast cancer cells in the development of resistance [10].

We observed rapid c-Src activation following E2 treatment. The phosphorylation of $\mathrm{c}-\mathrm{Src}$ is required for correct binding of c-Src to ZO-1, which was demonstrated in MCF-7 and T47D 
cells. This observation was in agreement with previous reports showing that formation of the c-Src/ZO-1 complex was related to increased paracellular permeability in MDCK cells. This mechanism involves disrupting protein-protein interactions within the multiple protein TJ complexes, including the displacement of ZO-1 and occludin from this complex [32].

Supporting the mechanistic model of estrogen-dependent TJ protein displacement, we analyzed ZO-1 and ZONAB nuclear translocation and demonstrated that E2 increased levels of both proteins in MCF-7 nuclei. This correlated with their disappearance from the cytoplasm (Fig. 2a, b, SV1 and $\mathrm{SV} 2$ ). It has been reported that ZONAB and ZO-1 are part of a pathway by which TJs can regulate epithelial cell proliferation [33]. ZONAB is a Y-box transcription factor that binds to the ZO-1 SH3 domain and modulates the expression of genes encoding proteins involved in differentiation and cell proliferation in normal epithelial [34] and uveal melanoma cells [35]. Both proteins, after specific stimulus, localize in the nucleus and bind to specific promoters containing an inverted CCAAT box (Y-box). The Y-box is present in the promoters of genes encoding HER2 and several cell cycle regulators, which operate in a cell density-dependent manner [5, 36, 37]. Transepithelial resistance and paracellular permeability studies in human vascular endothelial (HUVEC) cell monolayers overexpressing ZO-1 and/or ZONAB demonstrated that the two proteins functionally interact at the HER2 promoter [38], suggesting that they might be part of a signaling system that could regulate epithelial differentiation, proliferation, and paracellular permeability in normal and transformed cells.

We demonstrated that estrogen induces changes in HER2 expression, presumably signaling along the ZO-1/ZONAB pathway. The use of CHX confirmed that changes in HER2 content were not due to de novo protein synthesis, implicating that those proteins originated through the displacement of TJ proteins from cell membranes. We incubated MCF-7 cells with low (1 nM) and high (100 nM) concentrations of E2 (Fig. 3a, b), with no apparent differences. It has been reported that estrogen can modulate ER alpha-induced HER2 expression in MCF-7 cells at 6-24 h of incubation, by interacting with ER beta in a dose-dependent manner [39].

Breast cancer cell lines such as MCF-7 and T47D are ER alpha-positive and dependent on estrogen for growth. The potential role of ER beta remains unknown. It has been clearly demonstrated that two ER beta isoforms (splice variants ER beta 1 and ER beta 2) have anti-proliferative functions when introduced into ER alpha-positive breast cancer cells, and ER beta 2 negatively regulates the transactivation of estrogen receptor alpha in MCF-7 cancer cells [40]. This is either by inducing proteasome-dependent degradation of ER alpha or repressing ER alpha-mediated transcriptional activity when co-expressed with ER alpha [22].

Another finding from our study was that estrogen upregulated ZO-1 and ZONAB in a time-dependent manner. To the best of our knowledge, estrogen response elements in the promoters of ZO-1 or ZONAB genes have yet to be reported. However, a mechanism has been described that supports our findings. Chen et al. suggested that Jun D regulates ZO-1 and ZONAB expression by forming the activator protein-1 (AP-1) transcription factor [41]. Their findings proposed the existence of a CREB site within the ZO-1 or ZONAB proximal promoter regions where AP-1 binds, inducing an interaction between ER and AP-1 and subsequent transactivation.

Estrogen significantly inhibits occludin expression at the mRNA and protein level after $24 \mathrm{~h}$. This was consistent with previous reports showing that estrogens are able to regulate occludin expression through ER beta in intestinal epithelial cells $[42,43]$. Sade et al. were the first to describe the occludin promoter and suggested tissue type-dependent expression. Occludin gene expression is augmented in brain endothelium and decreased in other endothelia in the presence of the same transcription factors, suggesting that ER beta might be a putative co-repressor in the occludin promoter [42].

The augmented translocation rate of ZO-1 and ZONAB to the nucleus or the downregulation of occludin affects $\mathrm{TJ}$ stability and promotes the ability of MCF-7 cells to acquire mesenchymal-like phenotypes and motility. To show that MCF-7 cells have these features, we evaluated the effects of E2 on the expression of CRB3, a novel epithelial marker [15], and N-cadherin, a mesenchymal marker. CRB3 is the human ortholog of the crumbs (CRB) protein and is required to establish the apical membrane, define the basolateral plasma domain, and has a fundamental function in the establishment of morphogenesis of 3D epithelial cell cultures [43]. CRB3 is a tumor suppressor during the transformation and progression of mammalian epithelial cells; its loss favors tumor cell growth, metastasis, and EMT $[15,44]$. We found that E2 downregulates CRB3 expression in MCF-7 cells; therefore, it is possible that CRB3 could be used as a novel marker in EMT, and its role in breast carcinogenesis has just begun to be unveiled.

It is worth noting that E-cadherin levels were not measured because it has been extensively reported that E2 downregulates its expression in normal and tumorigenic breast epithelial cells [45]. We sought to study changes in the expression and localization of CRB3 (apical) and occludin (basolateral) as epithelial markers of EMT-associated processes, rather than the direct effect of E2 on the expression of these proteins. On the other hand, gradual increases of $\mathrm{N}$-cadherin expression in these breast cancer cell lines were related to EMT-associated mechanisms, regardless of the E-cadherin expression [46], and could be used as stage markers during invasion processes. Furthermore, it has been reported that $\mathrm{N}$ cadherin expression correlates with invasion and motility, plays a direct role in promoting motility, and is involved in EMT and cancer cell metastasis [47]. There are contradictory reports on the effects of estrogen on $\mathrm{N}$-cadherin expression in 
different cell models; in most cancer cells, it has been shown to negatively regulate $\mathrm{N}$-cadherin induced by the ER signaling pathway [47]. We suggest that high $\mathrm{N}$-cadherin levels initiate EMT but through a different method by which estradiol directly affects breast cancer cells.

In conclusion, we showed that rapid extranuclear signaling of the c-Src/ZO-1/ZONAB cascade is relevant for the generation of estrogen-dependent EMT-associated mechanisms and migration in MCF-7 cells. We have demonstrated how E2 possibly induces disruptions to $\mathrm{TJ}$ formation through $\mathrm{c}-\mathrm{Src}$ activation; in turn, this leads to ZO-1 and ZONAB nuclear translocation, occludin downregulation, and HER2 transactivation. These changes correlate with the loss of epithelial characteristics, the acquisition of a mesenchymal phenotype, and estrogen enhances motility in ER-positive breast cancer cells, features that are required for breast cancer invasiveness and metastasis. We believe that our findings represent important clinical targets for developing new therapies against breast cancer progression before the onset of metastasis.

Acknowledgments The authors want to thank the Confocal Microscopy Core at DCBS-UAM for their assistance with image acquisition and analysis and the Divisional Molecular Biology Laboratory at DCBSUAM for their technical support. This study was partly supported by DCBS-UAM and the ICYTDF-UAM Nanotechnology projects. JEJ-S, PP-R, and G D-G are recipients of scholarships from CONACYT and are enrolled in the Experimental Biology Graduate Program (212870) at UAM (Mexico)

Conflict of Interest The authors declare that they have no conflicts of interest.

\section{References}

1. Jemal A, Siegel R, Ward E, Murray T, Xu J, Thun MJ (2007) Cancer statistics. CA Cancer J Clin 1:43-66

2. Hemminki K, Bevier M, Sundquist J, Hemminki A (2013) Sitespecific cancer deaths in cancer of unknown primary diagnosed with lymph node metastasis may reveal hidden primaries. Int J Cancer 4: 944-950

3. Yu M, Bardia A, Wittner BS, Stott SL, Smas ME, Ting DT, Isakoff SJ, Ciciliano JC, Wells MN, Shah AM, Concannon KF, Donaldson MC et al (2013) Circulating breast tumor cells exhibit dynamic changes in epithelial and mesenchymal composition. Science 6119: 580-584

4. Micalizzi DS, Farabaugh SM, Ford HL (2010) Epithelialmesenchymal transition in cancer: parallels between normal development and tumor progression. J Mammary Gland Biol Neoplasia 2: 117-134

5. Balda MS, Matter K (2000) The tight junction protein ZO-1 and an interacting transcription factor regulate ErbB-2 expression. EMBO J 19:2024-2033

6. Sanchez AM, Flamini MI, Baldacci C, Goglia L, Genazzani AR, Simoncini T (2010) Estrogen receptor-alpha promotes breast cancer cell motility and invasion via focal adhesion kinase and N-WASP. Mol Endocrinol 11:2114-2125
7. Planas-Silva MD, Waltz PK (2007) Estrogen promotes reversible epithelial-to-mesenchymal-like transition and collective motility in MCF-7 breast cancer cells. J Steroid Biochem Mol Biol 1-2:11-21

8. Zheng S, Huang J, Zhou K, Zhang C, Xiang Q, Tan Z, Wang T, Fu X (2011) 17ß-Estradiol enhances breast cancer cell motility and invasion via extra-nuclear activation of actin-binding protein Ezrin. PLoS ONE 7:e22439

9. Sudhagar S, Sathya S, Lakshmi BS (2011) Rapid non-genomic signalling by $17 \beta$-oestradiol through $\mathrm{c}$-Src involves mTORdependent expression of HIF- $1 \alpha$ in breast cancer cells. Br J Cancer 7:953-960

10. Vallabhaneni S, Nair BC, Cortez V, Challa R, Chakravarty D, Tekmal RR, Vadlamudi RK (2011) Significance of ER-Src axis in hormonal therapy resistance. Breast Cancer Res Treat 2:377-385

11. Van Slambrouck S, Steelant WF (2007) Clustering of monosialylGb5 initiates downstream signalling events leading to invasion of MCF-7 breast cancer cells. Biochem J 401:689-699

12. Hsia DA, Mitra SK, Hauck CR, Streblow DN, Nelson JA, Ilic D, Huang S, Li E, Nemerow GR, Len J et al (2003) Differential regulation of cell motility and invasion by FAK. J Cell Biol 160:753-767

13. Takenaga Y, Takagi N, Murotomi K, Tanonaka K, Takeo S (2009) Inhibition of Src activity decreases tyrosine phosphorylation of occludin in brain capillaries and attenuates increase in permeability of the blood-brain barrier after transient focal cerebral ischemia. $\mathrm{J}$ Cereb Blood Flow Metab 6:1099-1108

14. Rao RK, Basuroy S, Rao VU, Karnaky KJ Jr, Gupta A (2002) Tyrosine phosphorylation and dissociation of occludin-ZO-1 and Ecadherin-beta-catenin complexes from the cytoskeleton by oxidative stress. Biochem J Pt 2:471-481

15. Harder JL, Whiteman EL, Pieczynski JN, Liu CJ, Margolis B (2012) Snail destabilizes cell surface Crumbs3a. Traffic 13:1170-1185

16. Martin TA, Mansel RE, Jiang WG (2010) Loss of occludin leads to the progression of human breast cancer. Int J Mol Med 26(5):723-734

17. Clavijo-Cornejo D, Enriquez-Cortina C, López-Reyes A, Domínguez-Pérez M, Nuño N, Domínguez-Meraz M, Bucio L, Souza V, Factor VM, Thorgeirsson SS, Gutiérrez-Ruiz MC, Gómez-Quiroz LE (2013) Biphasic regulation of the NADPH oxidase by HGF/c-Met signaling pathway in primary mouse hepatocytes. Biochimie 6:1177-1184

18. Revillion F, Pawlowski V, Lhotellier V, Louchez MM, Peyrat JP (2003) mRNA expression of the type I growth factor receptors in the human breast cancer cells MCF-7: regulation by estradiol and tamoxifen. Anticancer Res 2B:1455-1460

19. Read LD, Keith D Jr, Slamon DJ, Katzenellenbogen BS (1990) Hormonal modulation of HER-2/neu protooncogene messenger ribonucleic acid and $\mathrm{p} 185$ protein expression in human breast cancer cell lines. Cancer Res 13:3947-3951

20. Lattrich C, Juhasz-Boess I, Ortmann O, Treeck O (2008) Detection of an elevated HER2 expression in MCF-7 breast cancer cells overexpressing estrogen receptor beta1. Oncol Rep 19:811-817

21. Dati C, Antoniotti S, Taverna D, Perroteau I, De Bortoli M (1990) Inhibition of c-erbB-2 oncogene expression by estrogens in human breast cancer cells. Oncogene 7:1001-1006

22. Haldosén LA, Zhao C, Dahlman-Wright K (2014) Estrogen receptor beta in breast cancer. Mol Cell Endocrinol 382:665-672

23. Vincent-Salomon A, Thiery JP (2003) Host microenvironment in breast cancer development: epithelial-mesenchymal transition in breast cancer development. Breast Cancer Res 2:101-106

24. Park SH, Cheung LW, Wong AS, Leung PC (2008) Estrogen regulates Snail and Slug in the down-regulation of E-cadherin and induces metastatic potential of ovarian cancer cells through estrogen receptor alpha. Mol Endocrinol 9:2085-2098

25. Zhu J, Lu X, Hua KQ, Sun H, Yu YH, Feng YJ (2012) Oestrogen receptor $\alpha$ mediates $17 \beta$-estradiol enhancement of ovarian cancer cell motility through up-regulation of survivin expression. Arch Gynecol 3:729-737 
26. Goto N, Hiyoshi H, Ito I, Tsuchiya M, Nakajima Y, Yanagisawa J (2011) Estrogen and antiestrogens alter breast cancer invasiveness by modulating the transforming growth factor- $\beta$ signaling pathway. Cancer Sci 8:1501-1508

27. Platet N, Cathiard AM, Gleizes M, Garcia M (2004) Estrogens and their receptors in breast cancer progression: a dual role in cancer proliferation and invasion. Crit Rev Oncol Hematol 1:55-67

28. Chen YJ, Li HY, Huang CH, Twu NF, Yen MS, Wang PH, Chou TY, Liu YN, Chao KC, Yang MH (2010) Oestrogen-induced epithelialmesenchymal transition of endometrial epithelial cells contributes to the development of adenomyosis. J Pathol 3:261-270

29. Thompson EW, Newgreen DF, Tarin D (2005) Carcinoma invasion and metastasis: a role for epithelial-mesenchymal transition? Cancer Res 14:5991-5995

30. Lösel R, Wehling M (2003) Nongenomic actions of steroid hormones. Nat Rev Mol Cell Biol 1:46-56

31. Migliaccio A, Castoria G, Di Domenico M, de Falco A, Bilancio A, Lombardi M, Barone MV, Ametrano D, Zannini MS, Abbondanza C, Auricchio F (2000) Steroid-induced androgen receptor-oestradiol receptor beta-Src complex triggers prostate cancer cell proliferation. EMBO J 20:5406-5417

32. Sabath E, Negoro H, Beaudry S, Paniagua M, Angelow S, Shah J, Grammatikakis N, Yu AS, Denker BM (2008) Galpha12 regulates protein interactions within the MDCK cell tight junction and inhibits tight-junction assembly. J Cell Sci Pt 6:814-824

33. Meyer TN, Hunt J, Schwesinger C, Denker BM (2003) Galpha12 regulates epithelial cell junctions through Src tyrosine kinases. Am J Physiol Cell Physiol 5:C1281-C1293

34. Lima WR, Parreira KS, Devuyst O, Caplanusi A, N'kuli F, Marien B, Van Der Smissen P, Alves PM, Verroust P, Christensen EI, Terzi F, Matter K, Balda MS, Pierreux CE, Courtoy PJ (2010) ZONAB promotes proliferation and represses differentiation of proximal tubule epithelial cells. J Am Soc Nephrol 3:478-488

35. Jayagopal A, Yang JL, Haselton FR, Chang MS (2011) Tight junction-associated signaling pathways modulate cell proliferation in uveal melanoma. Invest Ophthalmol Vis Sci 1:588-593

36. Nie M, Aijaz S, Leefa Chong San IV, Balda MS, Matter K (2009) The Y-box factor ZONAB/DbpA associates with GEF-H1/Lfc and mediates Rho-stimulated transcription. EMBO Rep 10:1125-31
37. Balda MS, Garrett MD, Matter K (2003) The ZO-1-associated Y-box factor ZONAB regulates epithelial cell proliferation and cell density. J Cell Biol 3:423-432

38. Ye L, Martin TA, Parr C, Harrison GM, Mansel RE, Jiang WG (2003) Biphasic effects of 17-beta-estradiol on expression of occludin and transendothelial resistance and paracellular permeability in human vascular endothelial cells. J Cell Physiol 2:362-369

39. Lattrich C, Juhasz-Boess I, Ortmann O, Treeck O (2008) Detection of an elevated HER2 expression in MCF-7 breast cancer cells overexpressing estrogen receptor beta1. Oncol Rep 3:811-817

40. Zhao C, Matthews J, Tujague M, Wan J, Ström A, Toresson G, Lam EW, Cheng G, Gustafsson JA, Dahlman-Wright K (2007) Estrogen receptor beta2 negatively regulates the transactivation of estrogen receptor alpha in human breast cancer cells. Cancer Res 67:3955-3962

41. Chen J, Xiao L, Rao JN, Zou T, Liu L, Bellavance E, Gorospe M, Wang JY (2008) JunD represses transcription and translation of the tight junction protein zona occludens-1 modulating intestinal epithelial barrier function. Mol Biol Cell 9:3701-3712

42. Sade H, Holloway K, Romero IA, Male D (2009) Transcriptional control of occludin expression in vascular endothelia: regulation by Sp3 and YY1. Biochim Biophys Acta 3:175-184

43. Braniste V, Leveque M, Buisson-Brenac C, Bueno L, Fioramonti J, Houdeau E (2009) Oestradiol decreases colonic permeability through oestrogen receptor beta-mediated up-regulation of occludin and junctional adhesion molecule-A in epithelial cells. J Physiol Pt 13:33173328

44. Martin-Belmonte F, Perez-Moreno M (2011) Epithelial cell polarity, stem cells and cancer. Nat Rev Cancer 1:23-38

45. Oesterreich S, Deng W, Jiang S, Cui X, Ivanova M, Schiff R, Kang K, Hadsell DL, Behrens J, Lee AV (2003) Estrogen-mediated downregulation of E-cadherin in breast cancer cells. Cancer Res 17:52035208

46. Nieman MT, Prudoff RS, Johnson KR, Wheelock MJ (1999) Ncadherin promotes motility in human breast cancer cells regardless of their E-cadherin expression. J Cell Biol 3:631-644

47. Zhang X, Liu G, Kang Y, Dong Z, Qian Q, Ma X (2013) N-cadherin expression is associated with acquisition of EMT phenotype and with enhanced invasion in erlotinib-resistant lung cancer cell lines. PLoS One 3:e57692 